\title{
The meaning of nursing 200 years after Nightingale - perceptions of professional practice in the intensivist context
}

\author{
O sentido da enfermagem 200 anos após Nightingale - percepções da prática profissional no contexto intensivista
}

El sentido de la enfermería 200 años después de Nightingale- percepciones de la práctica profesional en el contexto intensivista

Emanuelle Caires Dias Araújo Nunes' ORCID: 0000-0002-0226-3619

Regina Szylit'

ORCID: 0000-0002-9250-0250

'Universidade de São Paulo. São Paulo, São Paulo, Brazil.

How to cite this article: Nunes ECDA, Szylit R. The meaning of nursing 200 years after Nightingale - perceptions of professional practice in the intensivist context. Rev Bras Enferm. 2021;74(2):e20200364. https://doi.org/10.1590/0034-7167-2020-0364

Corresponding author:

Emanuelle Caires Dias Araujo Nunes E-mail: emanuelecdanunes@gmail.com

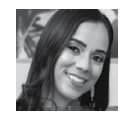

EDITOR IN CHIEF: Antonio José de Almeida Filho ASSOCIATE EDITOR: Rafael Silva

Submission: 07-09-2020

Approval: 01-02-2021

\begin{abstract}
Objectives: to know the meaning of contemporary nursing from the experience of intensive care nurses. Methods: qualitative research based on the theoretical framework of Symbolic Interactionism and the methodological framework of Interpretive Interactionism. The setting was a general hospital in Bahia, being carried out with 12 nurses working in intensive care for at least one year, through semi-structured interviews and drawing-text-theme technique, whose data were organized according to Miles and Huberman and analyzed upon the referential. Results: the sense of being a nurse was evidenced; a being for care, resulting from the experience in intensive care, capable of promoting the development of professional self-image, by causing, in nurses, other skills - besides the scientific ones, such as empathy, creativity, spirituality and compassion. Final Considerations: the sense of being a nurse, currently, expresses developments inherited from the Nightingalean proposal, but transcends the technical-managerial emphasis of this to a humanistic care perspective converging with our contemporary professional identity: a being for care.

Descriptors: Nursing; Professional Practice; Perception; Intensive Care Units; Empathy.
\end{abstract}

\section{RESUMO}

Objetivos: conhecer o significado da enfermagem contemporânea a partir da experiência de enfermeiros da Terapia Intensiva. Métodos: pesquisa qualitativa sob o referencial teórico do Interacionismo Simbólico e referencial metodológico do Interacionismo Interpretativo, desenvolvida em um hospital geral da Bahia, com 12 enfermeiros da terapia intensiva. Foram realizadas entrevistas semiestruturadas e aplicada a técnica desenho-texto-tema, cujos dados foram organizados segundo Miles e Huberman e analisados mediante o referencial. Resultados: evidenciou-se o sentido de ser enfermeiro; um ser para o cuidado, tecido no decorrer da experiência na terapia intensiva, capaz de promover a elaboração da autoimagem profissional ao mobilizar, nos enfermeiros, outras habilidades para além das científicas, tais como empatia, criatividade, espiritualidade e compaixão. Considerações Finais: o sentido atual de ser enfermeiro expressa desdobramentos herdados da iniciativa nightingaliana, mas transcende a ênfase técnico-gerencial desta para uma perspectiva humanística assistencial convergente com a nossa contemporânea identidade profissional: um ser para o cuidado. Descritores: Enfermagem; Prática Profissional; Percepção; Unidades de Terapia Intensiva; Empatia.

\section{RESUMEN}

Objetivos: conocer el significado de la enfermería contemporánea partiendo de la experiencia de enfermeros de Terapia Intensiva Métodos: investigación cualitativa fundamentada en el referencial teórico del Interaccionismo Simbólico y en el Referencial Metodológico del Interaccionismo Interpretativo. Realizado en un Hospital General de la Bahía, con 12 enfermeros que actúan en la terapia Intensiva hace un año, sometidos a entrevista semiestructurada y al diseño-texto-tema cuyos datos fueron organizados según Miles y Huberman, analizados usando el referencial. Resultados: manifiesta el sentido de ser enfermero, un ser para el cuidado, formado a partir de la experiencia en terapia intensiva, que promueve la elaboración de la autoimagen profesional, al estimular en los enfermeros, otras habilidades además de las científicas, como: empatía, creatividad, espiritualidad y compasión. Conclusiones: el ser enfermero actualmente expresa, desdoblamientos heredados de la iniciativa nightingaliana, que va desde un énfasis técnico-gerencial, a una perspectiva humanística asistencial convergente con nuestra identidad profesional contemporánea: un ser para el cuidado. Descriptores: Enfermería; Práctica Profesional; Percepción; Unidad de Terapia Intensiva; Empatía. 


\section{INTRODUCTION}

Think over the history of nursing in the person of Florence Nightingale is to come across a unique reference of contribution to the science of nursing. In 1859, when she published Notes on Nursing, Nightingale had a great impact on society at the time because of her trustworthiness and respect. The so-called lady of the lamp created, based on voluntary experiences with patients and hospitals, a systematic and empirical approach that greatly contributed to the improvement of the sanitary conditions of those establishments and people's understanding of the wide patients' care needs $s^{(1)}$.

Florence's legacy is a reason of joy for nurses, for the achievements and changes she has established in the treatment of patients, in the relationship of nursing with human beings, with the environment and with health, which are still so important today ${ }^{(2)}$. For this reason, the professional choice for nursing persists motivated by the wish to care for others, to contribute to help others, especially in times of vulnerability in their health and life. This meaning gives nursing a different connotation, a mission status, which gives its team, besides professional reward, a precious personal accomplishment ${ }^{(3)}$.

Nightingalean nursing, however, was predominantly portrayed by the management of the environment and its hygiene in a context almost restricted to hospital wards $s^{(2)}$. Two centuries later, the nurse's performance scenarios have greatly diversified. New and creative perspectives for nurses have emerged regarding the labor market and, thus, there are several specialties, with promising activities that enable the possibility of choosing a context more like the personal preferences ${ }^{(4)}$.

Modern nursing, therefore, although keeping the primacy of care in common, advances in new ways/environments, which possibly consist of the main modifying element of contemporary professional identity ${ }^{(5)}$. The social interaction that these workers have developed upon the new demands, therefore, represents the main determining element of professional meaning - which has been changed since the times of Florence to nowadays.

Therefore, it is expected that the contemporary meaning of "being a nurse" can be better known from the study of the experience of these professionals today. For this reason, this work gathers, as a theoretical reference, Symbolic Interactionism, a contribution that comprises human behavior as a product of the symbols that the individual undertakes as significant throughout his social interaction. In other words, the person changes and modifies his way of acting and behaving according to the senses acquired throughout the experience of interaction, always dynamic and transforming throughout life ${ }^{(6)}$. In this way, by the perspective of the chosen framework, we can investigate the nurse human being's perceptions and certain actions depending on the place he/she is at, based on the symbols and meanings he/she has developed in his/her professional praxis.

This challenge takes place in the Intensive Care Unit (ICU), chosen because it is an environment rich in care needs that challenge the skills of these professionals from technological, technoscientific aspects to those related to human relationships and weaknesses, especially expressed in the common risk of death they live with ${ }^{(7)}$. The ICU, then, is an opportune space for the stimulation of professional conscience, by capturing the values, attitudes and senses of care that permeates patient and family affected by the fear and anxiety peculiar to the critical condition.

The ICU context challenges nurses to interact with others in their humanistic, existential, and spiritual dimensions that reveal a new status of their role in human care ${ }^{(7)}$. This fact, which is not exclusive to intensive care, contributes to the growth of nursing awareness, raising the way he/she reflects on his/her experiences and mobilizes her praxis beyond the current limitations, to embrace human care in a sacred and deep way, in an expanded perspective of the meaning of how to be-to-know the theoretical-practical nursing science ${ }^{(8)}$. Therefore, this study deals with the contemporary experience of nursing in everyday intensive care, seeking to explore the meanings and values perceived by intensive care workers in directing their current professional identity, which confirms a knowledge gap that is always recurring and never exhausted. Therefore, this research assumes a dilemma: "What is the meaning of contemporary nursing in the experience of nurses in Intensive Care?", Whose results will be analyzed making a comprehensive parallel of how the meaning of nursing has evolved from Nightingale until today.

\section{OBJECTIVES}

To know the meaning of contemporary nursing from the experience of intensive care nurses.

\section{METHODS}

\section{Ethical aspects}

The study was developed following the ethical precepts of Resolution no. 466/12, of the National Health Council, having been approved by the Research Ethics Committee of the Escola de Enfermagem da Universidade de São Paulo (School of Nursing at the University of São Paulo). The participants accept to participate in the research, by signing the Informed Consent Form. Participants were identified by the letter P plus sequential numbers, P1, P2 and so on, to ensure privacy.

\section{Theoretical-methodological framework}

The theoretical framework selected was Symbolic Interactionism, being supported by the methodological framework of Interpretive Interactionism regarding the content analysis. This methodological foundation consists of a methodology that understands the meanings of the actions based on the lived experiences. In this perspective, its strategy focuses on the search for in-depth reports of personal experiences, capable of revealing symbolic elements, that is, significant elements, which influence human actions in contexts of complex interactions. Through this method, then, meanings attained by the subject can be interpreted in the interaction with a certain context, capable of modifying their action and their professional attitude, which occurs dynamically and continuously in the endless process of human interaction - a constant acquisition of new meanings that trigger new attitudes based on the meaning they assume in the process of being in the world of each subject ${ }^{(6)}$. 


\section{Study type}

This is a study of qualitative approach and interpretative nature based on Symbolic Interactionism and guided by the COREQ tool. Data analysis was mediated by the interactive content model.

\section{Setting}

The research was carried out in a state hospital, a center for urgency and emergency for the southwestern region of Bahia, considered with a high level of care. Data collection was carried out in the three adult ICU units of the institution, which make up a total of 39 beds. The researcher did not have any professional ties in the study setting.

\section{Data source}

The participants were 12 nurses working in the units, selected by non-probabilistic means, due to accessibility, observing the inclusion criterion of having at least one year of experience in the ICU, which aimed to guarantee a consistent experience in such scenario. Those nurses who were on leave or vacation throughout the collection period were excluded. They were outlined by theoretical data saturation, that is, the moment when the collected material, through concomitant analysis, revealed redundancy and robustness regarding its content ${ }^{(9)}$.

\section{Data collection and organization}

The methodological procedures consisted of using the semi-structured interview and the drawing-text-theme. The semi-structured interview was used with short and reflective questions, to allow the development of freer and more in-depth reports about the subjects' experience. It consisted of the script: "How do you understand yourself as a nurse?", "Who are you in the context of the ICU?" and "Tell me about your care experience in the context of Intensive Care?". The drawing was chosen as a strategy capable of expressing metaphorical symbols chosen by nurses as significant in their care process. For its completion, the material made available was graphite pencil, rubber, black hydrographic pen, and white drawing sheet with $10 \times 18 \mathrm{~cm}$ delimitation margins. The design was constructed from the following stimulus: "Draw something that you would offer to the patient/family member in the ICU as the best symbol of your care". After the drawing was finished, the participant was asked to explain his art and then he was asked to assign a title/theme. The text and the title are used to anchor the image, enabling its analysis and interpretation, based on speech ${ }^{(10)}$. Both collection techniques were applied to the consenting participant by the main researcher of this study, a doctoral student dedicated exclusively to the course (CNPq fellow), female, with previous experience in the use of these techniques.

The closeness between the researcher and the participants occurred through personal contact in the study setting (ICU). At the first contact, the interviewer presented herself regarding her status, her origin, and her interest/theme, besides explaining the purpose of the study. After consent, by signing the informed consent form, the data collection step was followed. The data collection process took place over one month, in the second semester of 2018, with both steps being performed at the same time and separately, with each participant. First, there was the interview and then the drawing, collected in a private place, during these professionals break during their shift at the unit of their assignment. In total, 12 nurses participated in the study, with only 1 refusal, due to the availability of time. The speeches referring to the two techniques were recorded and transcribed, enabling content analysis. The average duration of the interviews was $22 \mathrm{~min}$.

\section{Data analysis}

Content analysis was carried out using the interactive categorization model proposed by Miles and Huberman ${ }^{(11)}$. This model involves the steps of data reduction, display, and interpretation for the analytical process. The reduction is the initial step and characterizes the search for codes consistent with the objectives of the study within the data set; that is, it allows the researcher to survey themes originated from the data. The coding was performed by the researcher responsible for data collection. Then, the codes were submitted to the second author for observation of consistency. The presentation consisted of structuring, organizing, and examining the information obtained from the data, while the interpretation involved the process of explaining and interpreting the finding $\mathrm{s}^{(11)}$. This whole process of organizing the data was carried out in the light of the methodological framework, which allowed for an accurate interpretation in the comprehensive direction of the meaning of the experience ${ }^{(6)}$. The results were organized in the interpretative axis, presented below.

\section{RESULTS}

The nurses interviewed had been graduated from 3 to 20 years, with a minimum of 1 year and a maximum of 20 years of experience in the ICU, the majority being female, 8 , aged from 28 to 46 years. The analysis of the data indicated to 2 categories: "Finding the nurse's identity in the intensive care context: a profession that exists to care" and "Mobilizing meanings of care in the context of the intensive care experience", which are divided into 3 and 4 subcategories, respectively.

The categories are presented below, intermixing the interviews with the drawings, in a complementary and convergent manner.

The first category of this study involves the contemporary self-perception of nurses from the context of intensive care which are 3: nurses understand themselves as the professional who spends more time with the patient and the family, which gives them a professional identity focused on relational care; the nurse perceives her/himself as a gifted professional, when reflecting on his/her relevance in intensive care context; and the nurse elaborates his/her self-image as a professional focused in the care relationship with the other person as well, interacting sensitivity and spirituality in the care process.

\section{Category 1: Finding the nurse's identity in the intensive care context: a profession that exists to care}

Category 1 is represented by Figure 1, Nursing, people who take care of people, made by participant $\mathrm{P} 1$, and covers 3 subcategories. 
Figure 1 is the only image signifying this category, as it encompasses the meanings expressed in the 3 subcategories gathered in this first axis.

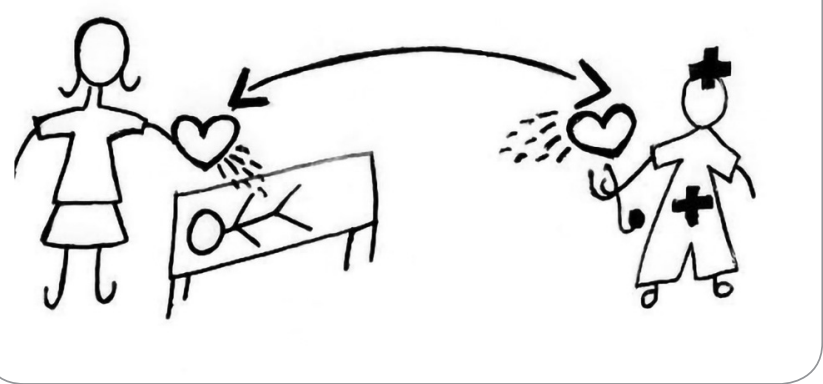

Figure 1 - Nursing, people who take care of people

My drawing means like [...]. When a family member brings the love for the patient, everything improves and the nurse, allied with that, comes, and combines their care as a partnership [...] this means love, responsibility, so the family member looks at the nurse and says: "I like this nurse when he is here", this is priceless [...]. Nursing means care, I always say. Nursing means people who like people, if you don't like people it makes no sense to be here! (P1 - Drawing)

\section{Subcategory 1a: Perceiving the professional identity of nursing in the care}

For me, the nurse is a comprehensive professional [...]. The nurse alone is a professional who must handle a little bit of everything; we are nurses, sometimes we also have to be a psychologist, give a word of comfort there [...] we are the leader of the nursing team and so on [...]. (P2)

[...] mainly the nursing is more attached to the patient, the family. When the family member arrives, the nursing team, the nurse goes there, but the doctor stops by once to make the report, the physiotherapist goes there when needed; so, I think the nurse is more directly connected to the family and the patient. (P3)

Nursing, the nurse is the key. The ICU does not work without the nurse, you organize the ICU and manage the patient, look at the patient in the big picture, report the complications to the doctor [...]. The nurse is involved in everything. (P4)

\section{Subcategory 16 : Finding a rewarding mission in nursing}

[...] more critical patients require care, greater responsibility [...] it is more care at the bedside, you perform greater care and give greater attention. (P5)

I see myself as a key role in the lives of many people, with a unique and rewarding responsibility, which is to help others [...], as a nurse, you can bring together compensation with work with this mission, the greatest mission of all: helping others, loving others, caring for others. (P7)

When I had the opportunity to enter here, my God, I found myself, you know, I found out that the nurse in the ICU does real hard work
[...] he is close to the patient, close to the assistance, he who gives the medications, he performs all the care and that made me think of myself as a nurse. (P1)

\section{Subcategory $1 \mathrm{c:}$ Interacting humanity in professional care practice}

Being in the ICU made me get to know myself better [...] I have already been to the neo, pediatrics and adult, so in each one I was could help with life coming back and with life-ending in all age groups. They surely are very different perceptions, it is difficult to see a child die [...] I used to think that the child's life was more important than the adult's life, because the child I always saw as a being who had a whole life ahead and the adult already had an opportunity to live, but today I changed my perception that lives are lives and every life that comes, it comes to be the love of someone and every life that goes away, will result in someone's sadness; so, it doesn't matter if you are an adult, if you are young, it will hurt the same way. (P7)

[...] it is a moment that you are there thinking this patient may be gone, and the patient also ends up thinking that he may die, or that he misses his grandson, his son, we start that expectation. So, we must give them positiveness, improve self-esteem, raise confidence, produce this good spirituality. (P8)

There was a death today, I was very sad, I even cried a little by myself [...] we are sad, because she is a patient that I thought she was going to get out. [...] I think it is important to start working with the family from the moment the patient enters the ICU to better understand the possibility of death. (P1)

\section{Category 2: Mobilizing meanings of care in the context of the intensive care experience}

Category 2 is defined through its 4 subcategories, illustrated individually, for bringing with them a certain difference, although each in its own way, converge equally in meanings of care in the researched context.

\section{Subcategory 2a: Connecting Care}

Subcategory 2a is represented by Figure 2, Dialogue, made by participant $\mathrm{P} 3$.

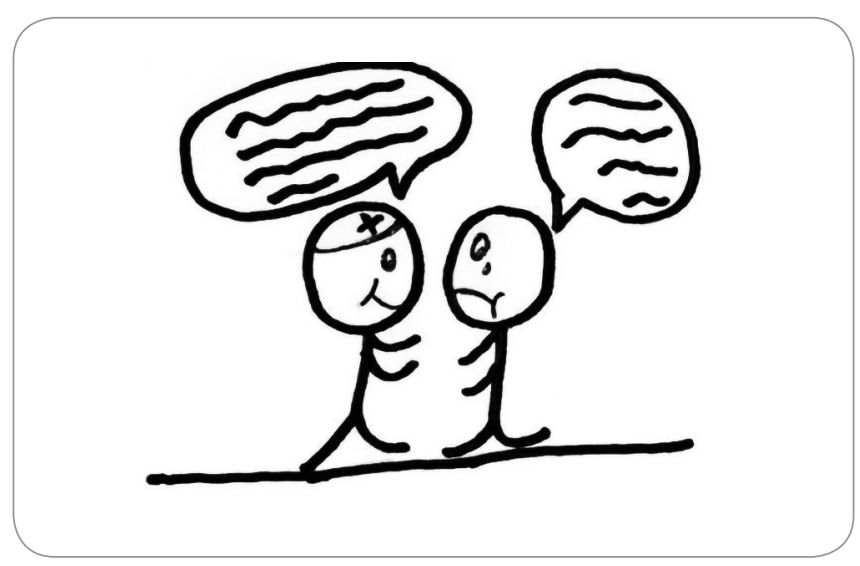

Figure 2 - Dialogue 
It would be in the case of dialogue, talking [...] is a matter of assisting mainly the awake patient, sometimes he does not want to eat, why does he not want to eat? He cries, why does he cry? He's anxious, why is he anxious? So, like this, you get to this patient, right? [...] you try to find what he has, if he is anxious, if he is sad. The same thing is with the family member, right? Try to get closer, try to seek help and interaction with the family; you have another view, a holistic view. (P3, Drawing)

It doesn't take much for you to answer some questions, don't walk away from some situations that can cause this approach, right? So, this communication needs to take place so that we can really embrace the needs of that family at that moment, I think it helps a lot for them to face that moment of anguish, anxiety, pain. (P9)

The family needs psychological care, that word of support, that different look, that kindness that, sometimes, just a smile and a 'good afternoon' shows confidence, trustworthiness [...]. (P10)

[...] so, when you can bring the family together and you can develop a relationship with the family, they trust more the facility, they believe more in people, they go home calmer [...] they go home leaving their loved one, who is always a relative, a son, a father, a mother, for the other to take care, but with that certainty or with that hope that he is being well taken care of, because of the relationship you established. (P7)

\section{Subcategory 2b: Empathic Care}

Subcategory $2 \mathrm{~b}$ is represented by Figure 3, Empathy, made by participant P10.

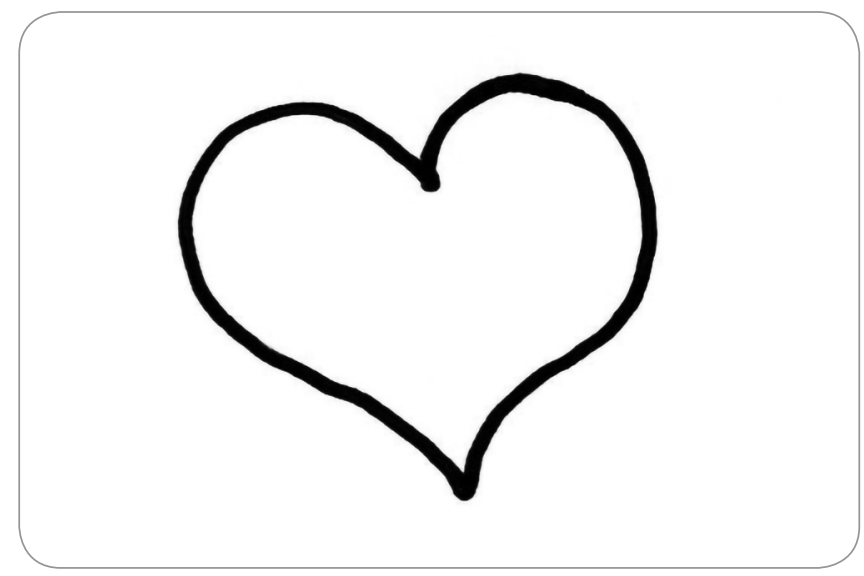

Figure 3 - Empathy

I think that love is the basis of everything; if you have love, other things are the result of it. If you love your profession, you love what you do, if you arrive here full of love to give, other things will be added. (P10, Drawing)

[...] sometimes people say: oh, this companion is too boring, that's it, that's that [...]. Then there was a time when I said: have you stopped to think what you are, suddenly, your life is interrupted to stay with a patient in the hospital, now you don't know if that patient is the home provider, [...] the person who leads the family and who suddenly goes off the scene. And what happens to that family? (P7)
[...] I saw myself on the other side, I saw myself as a relative of the ICU patient, so today I realize that I have changed my opinion on this. This experience I had, of having seen a friend who did not assist me, you know [...]. I saw a mechanical thing, I saw something that I would not like to go through, so I learned a lot, today I see it with differenteyes [...] the issue of assistance, of not only getting there and giving medicine and turning away instead of welcoming, knowing how to embrace, knowing how to explain, giving attention. (P3)

I try to put myself in the other's place, so I think like this: if it were me lying there, what would I want? Putting up a picture or photos [...] bringing in books, music. (P12)

[...] there was a big patient burned by electric shock and he lost both legs [...] he had already given up, he thought he was going to die, I managed to bring his children with him, after that he recovered [...] sometimes, we must run over some rules, because the children were minors, they could not enter, but we have to do something to do better to the patient. (P11)

\section{Subcategory 2c. Scientific Care - Realizing the responsibility of scientific knowledge in intensive care}

Subcategory $2 c$ is represented by Figure 4, Humanization, made by participant P9.

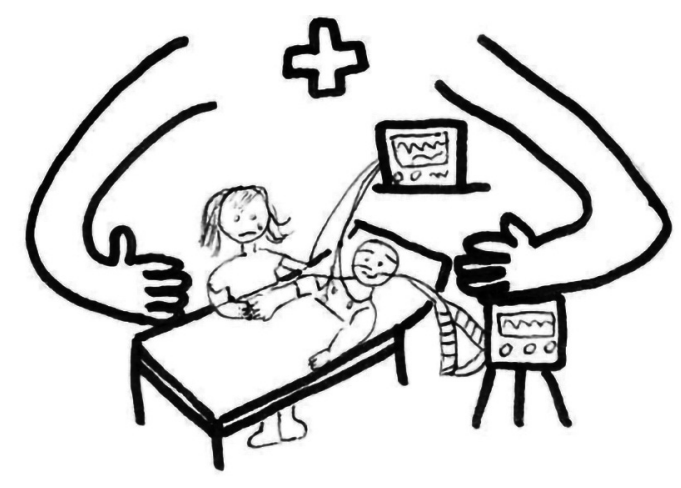

Figure 4 - Humanization

I draw here a critical patient, an intubated patient, a patient looking concerned and a sad family member at the bedside, someone from the family, very tearful and the arms here I put the cross to represent the nursing and it is a very big hug so, the big arms around this whole context, which is the family, the critical patient, and this process of illness, right? And nursing embracing not only one or the other, but embracing the whole process. (P9, Drawing)

[...] I like a critical patient, I like the emergency condition, I like the critical patient and I feel prepared and useful at that moment when they are very critical, and I also like it when they are very well, and then they can go to the Clinic and return to the family. (P6)

I see myself with great responsibility because we take the patient at a time when the other units, the other inpatient resources, no longer can be effective. So, we are at the top of the assistance, you know? In this patient's moment of fragility, I see myself with a great responsibility [...] to be competent, to try to identify any clinical abnormality [...]. (P9) 
[...] we studied and we must have this scientific preparation to, in this case, deal with it; so, I think we must do our best [...]. (P2)

[...] it is a science, right? [...] the science of caring, it is not just a matter of managing the patient [...] there is a science behind caring [...] there are the proper techniques that you will use. (P8)

\section{Subcategory 4d. Spiritual care - Finding meaning in caring for the soul}

Subcategory $2 \mathrm{~d}$ is represented by Figure 5, Hope, made by participant $\mathrm{P} 2$.

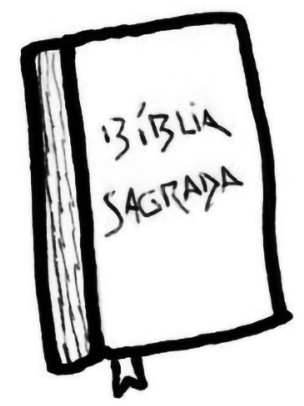

Figure 5 - Hope

In this moment of suffering, I would offer a Bible that is a symbol of faith and brings hope. Of course, we must respect each other's religion, but I would offer a bible as a source of comfort for those people who believe. (P2, Drawing)

It is like a saying that says: master all sciences, all theories, but when touching a soul, a patient, remember that he is a human being, he has a soul. So, I think that all this should be considered [...] it is useless to know all the techniques [...] the whole Intensive Care Unit protocol, without considering the inner aspect of the patient and family members [...] we see tears coming down, so sometimes I say a prayer that they ask, I ask are you an evangelical? Catholic? I mean, regardless of the religion [...]. (P8)

Ah, there is another part that is also of religiosity, that many of them ask to bring the pastor, to bring the priest and we let them in. [...] we guide them to wear the coat, wash hands, they put the oil on, pray [...] we leave, because you have to respect this religious part and it is important even for the family, when you have the loss, to have the feeling they had done everything. (P4)

\section{DISCUSSION}

The findings achieved in this study show progress in the meaning of care, object of nursing, from Florence Nightingale's contributions to date. The meaning recognized in this study presents nursing care from a polysemic perspective as to its dynamic and always subjective meaning. Such reading is certainly driven by the symbolic social transformations that are built in human-human interaction; an interactionist understanding that explains the understanding discussed here ${ }^{(6,12)}$.
Care is already shown as a polysemic concept by an important study of the area that discusses its properties in three senses: existential, relational, and contextual. In the existential perspective, care is part of being and differentiates it as a human being endowed with rationality, cognition, intuition and spirituality; therefore, with sensitivity and feelings. It is also relational, because it only occurs in coexistence with other beings; that is, it is an interactive activity that develops between the being who cares and the being who is cared for - involving engagement and commitment. And, still, contextual, by assuming variations in their ways and expressions of care, according to the environment in which they present themselves at each moment ${ }^{(3)}$. However, its relational aspect is what is best presented in this analysis, as it is understood because of the social action of each of the actors involved in its process - a process that is constructed on the interface of multiple and dependent aspects, such as effective communication, good relationships between professionals and patients, interdisciplinary work, sharing information and meanings, besides adequate coordination and integration.

Understanding care, then, involves subjectivity and sensitive reflection about its essence and intrinsic meaning in the intentionality and action of each agent in the process ${ }^{(12)}$. In the case of the ICU, the environment is favorable to nurse's satisfaction, especially due to the work organization, which can be expanded through good relations and the experience of autonomy, participation in the control of practices, decision making, management and organizational support for work - a routine that creates meaning for ICU nurses, providing them with knowledge, inspiration and work motivation ${ }^{(13)}$.

Other sources of pleasure in the work of the nursing team are associated with the acknowledgement of the assistance provided by the patient and the family, the possibility of recovery and improvement of the patient's clinical condition, besides the opportunity to develop embracement and empathy skills for others, especially in end-of-life circumstances ${ }^{(14)}$.

In this context, the nursing professional can rediscover oneself by taking care not only to re-establish the physiological functions, but to the mental-emotional-spiritual growth of the "patient and family" system, in the perspective of giving new meaning to this experience ${ }^{(8)}$. The nurse can offer his/her presence at this moment, approaching, touching, whispering words of comfort and courage that mobilize the patient to find peace and provide a serene and grateful passage through life ${ }^{(15)}$ These attitudes are confirmed by the findings of other studies also carried out in an ICU context $\mathrm{t}^{(7,13-14,16)}$. In this sense, although the current health context, especially in the ICU, is marked by the use of increasingly modern technologies, for the nurse, the need to develop more humanistic care, based on ethical skills and competencies and the professional attitude of valuing subjectivity ${ }^{(16)}$. It is the nurse's personal ability to "be for care", more relational care, which moves through the meanings, discovered only in the complete interaction with the other, at the level of feelings, thoughts, and spirit ${ }^{(8,15)}$.

This interaction, therefore, exposes the crucial elements for effective care, which are described in the second axis and affect relational attitudes, such as connection, dialogue, closeness, empathy, creativity, spirituality, and sensitivity - perceived as essential in the caring interaction of the nurse-patient-family. This understanding finds validity in the expectations of family 
members ${ }^{(17)}$, which, observed by specific studies, points out as important the specialized physical assistance, combined with the fulfillment of emotional needs and with the continuous support in this complex environment.

Thus, what the family and the patient expect from the nursing professional is the focus on compassion during care, through their maturity, the ability for empathy and the commitment to, besides accomplishing their tasks, being committed to the true well-being of the other ${ }^{(17)}$. Therefore, communication in the ICU is evidenced, in other research, as an important element for care $^{(7,13-14,16-17)}$. Its construction can be improved through the development of skills and abilities - how to listen, respect, face difficult conversations, manage conflicts, and develop palliative care, including emotional support. Nurses who can practice this interaction, promote a positive environment, boost patient and family satisfaction and develop good communication also with the multi-professional team, greatly favoring the critical care process. In this sense, meetings between the ICU health team are encouraged, as well as educational actions for professionals who are facilitators of the quality of care provided ${ }^{(6,18)}$.

Spirituality is another element to be nurtured in the process of non-material care. The stimulus/acceptance of faith is proven to be effective in critical patients' therapy, by mobilizing the forces that lead them to express senses that are right to their resilience ${ }^{(8)}$. Thus, the spiritual dimension reveals its own healing force, which is mobilized, in being, through the energy of love, solidarity, connection, compassion and mercy ${ }^{(15)}$. In this sense, the development of artistic activities that emphasize care and results focused on the individual is very opportune, because the openness to creativity demonstrates, in this process, positive impacts for patients, families, staff and the environment ${ }^{(18)}$. Music, for example, has been a useful element in differentiated care for patients and families. It optimizes humanization, by expanding the range of resources beyond the typical technological arsenal of ICUs, promoting interaction with the emotional dimension of the other and oneself ${ }^{(19)}$.

Given this, the findings of this study corroborate those of other articles ${ }^{(14,16,20)}$, as they allow us to confirm that assisting critical patients requires much more than academic knowledge, as it provides the bioethical attitude of embracing and resizing everyday professional experience and opening up to meet humanistic care, fostering a professional identity that adds social value to the group ${ }^{(6,20-21)}$. After all, care reveals itself much more as an art than as a technique and presupposes, in the health professional, a density of life, spiritual sense and affection. It is, therefore, within the scope of interiority that the world of excellence emerges and the values and attitudes that move the being towards the effective action of care come from ${ }^{(15)}$.

Therefore, the contemporary identity of nursing, perceived in this study, reflects a broadened meaning from the understanding that nurses must "be" a care response to the call for help - be it physical, emotional, or spiritual. The sense of becoming a being for care, therefore, exceeds the restricted acquisition of theoretical and practical knowledge of the area, because it recognizes, further than this, the need for personal maturity that enables specific relational skills and abilities, only perceived in the inner personal decision to learn to be, to change and to become continuously, interacting with people, their contexts, and their specificities.
The lenses of Symbolic Interactionism allowed, in this context, to understand that nurses are constructed themselves as beings of care, from the care relationship they establish with the critical patient and their family, mobilizing attitudes and behaviors that are ennobling of their function. In highlight, the dialogue, the bond, the love, and the dedication became evident in this care process, which is characterized by being creative, artistic, sensitive, compassionate, and comprehensive to being with whom a real empathic encounter is established.

\section{Study limitations}

The limitations of this study are linked to the researched scenario, which may not represent a generalizable context. Thus, investment in more research is encouraged to explore and better understand the senses and meanings of the experience of nurses in different scenarios, which will certainly contribute to a broaden understanding of the professional identity of contemporary nursing.

\section{Contributions to the Area}

This research contributes to nursing by adding to the literature of the area unique evidence about the contemporary meaning of nursing. Its findings point to a redefined logic of being a nurse, which preserves the essence of care, but advances in the incorporation of new meanings to its praxis, in the comprehensive direction of adding technical ability, sensitivity, affectivity and spirituality in the relational encounter between the nurse and the person being cared for.

Thus, we observe a logical transition when we draw the parallel between the before (nightingalean context) and the now (today's context). In its early days, nursing had the environment as the most urgent form of health promotion - given the scientific and structural precariousness of the time. Today, however, we have a great advancement in these aspects: a huge and continuous collection of scientific evidence and health laws, besides an organized health care structure. In this new context, therefore, what represents the greatest demand for nursing is no longer focused on the environment external to the nurse, but rather on the interiority. Being a nurse nowadays focuses on the competence to transfer the focus of our efforts to the inner attitude of relational care with oneself and with others.

\section{FINAL CONSIDERATIONS}

The study showed the meaning of contemporary nursing, from the experience of Intensive Care nurses. Its findings point to a new meaning of the caregiver's role, which remains the central axis of the profession, but advances in different directions over time, assuming a much more relational and subjective character than before. It is a profession that, these days, is more in tune with the human and social sciences than strictly with medical and health science, since it is built from the biopsychospiritual needs of being that can only be contemplated in an authentic help relationship, based on in the interaction between objectivity and subjectivity, the body and the soul, the self and the other, 
science and faith. This understanding employs a transforming power on nurses that goes through self-knowledge and reaches professional maturity as the awareness of their identity, the exact role and the polysemic meaning that nursing has in the social sphere of human care is built.

\section{FUNDING}

This study was financed in part by the Coordenação de Aperfeiçoamento de Pessoal de Nível Superior - Brasil (CAPES) - Finance Code 001 and CNPq.

\section{REFERENCES}

1. Bezerra CMB, Silva BCO, Silva RAR, Martino MMF, Monteiro Al, Enders BC. Análise descritiva da Teoria Ambientalista de Enfermagem. Enferm Foco. 2018;9(2):79-83. https://doi.org/10.21675/2357-707X.2018.v9.n2.1105

2. Reynolds NR. The year of the nurse and midwife 2020: activating the potential and power of nursing. Rev Latino-Am Enfermagem. 2020;28:e3279. https://doi.org/10.1590/1518-8345.0000-3279

3. Waldow VR. Enfermagem: a prática do cuidado sob o ponto de vista filosófico. Investig Enferm Imag Desarr. 2015;17(1):13-25. https://doi. org/10.11144/Javeriana.IE17-1.epdc

4. Souza CFQ, Oliveira DG, Santana ADS, Mulatinho LM, Cardoso MD, Pereira EBF, et al. Evaluation of nurse's performance in telemedicine. Rev Bras Enferm. 2019;72(4):933-9. https://doi.org/10.1590/0034-7167-2018-0313

5. Saint-Clair Teodosio S, Padilha MI. "To be a nurse": a professional choice and the construction of identity processes in the 1970 s. Rev Bras Enferm. 2016;69(3):428-34. https://doi.org/10.1590/0034-7167.2016690303i

6. Blumer H. Symbolic Interactionism: perspective and method. California: University of California Press; 1969. 244 p.

7. Braitt LA, Oliveira SRD. Guia para o processo de ajuda interpessoal de enfermagem ao familiar do paciente crítico. Cienc Enferm. 2017;23(2):159-69. https://doi.org/10.4067/S0717-95532017000200159

8. Rosa W, Estes T, Watson J. Caring science conscious dying. Nurs Sci Q. 2016;30(1):58-64 https://doi.org/10.1177/0894318416680538

9. Saunders B, Sim J, Kingstone T, Baker S, Waterfield J, Bartlam B, et al. Saturation in qualitative research: exploring its conceptualization and operationalization. Qual Quant. 2018;52(4):1893-907. https://doi.org/10.1007/s11135-017-0574-8

10. Bauer MW, Gaskell G. Pesquisa qualitativa com texto, imagem e som: um manual prático. 10a ed. Petrópolis: Vozes; 2012.516 p.

11. Miles MB, Huberman M, Saldaña J. Qualitative data analysis: a methods sourcebook. 3rd ed. Thousand Oaks (CA): Sage Publications; 2014.381 p.

12. Utzumi FC, Lacerda MR, Bernardino E, Gomes IM, Aued GK, Sousa SM. Continuidade do cuidado e o Interacionismo Simbólico: um entendimento possível. Texto Contexto Enferm. 2018;27(2):e4250016. https://doi.org/10.1590/0104-070720180004250016

13. Flinterud SI, Moi AL, Gjengedal E, Narvestad GL, Muri AK, Ellingsen S. The creation of meaning: intensive care nurses' experiences of conducting nurse-led follow-up on intensive care units. Intens Crit Care Nur. 2019;53(1):30-6. https://doi.org/10.1016/j.iccn.2019.03.009

14. Oliveira EM, Barbosa RL, Andolhe R, Eiras FRC, Padilha KG. Nursing practice environment and work satisfaction in critical units. Rev Bras Enferm. 2017;70(1):79-86. https://doi.org/10.1590/0034-7167-2016-0211

15. Gomes ET, Brandão BMGM, Abrão FMS, Bezerra SMMS. Contributions by Leonardo Boff for the understanding of care. Rev Enferm UFPE. 2018;12(2):531-6. https://doi.org/10.5205/1981-8963-v12i2a23563p531-536-2018

16. Lima AA, Jesus DS, Silva TL. Densidade tecnológica e o cuidado humanizado em enfermagem: a realidade de dois serviços de saúde. Physis. 2018;28(3):e280320. https://doi.org/10.1590/s0103-73312018280320

17. Mclean C, Coombs M, Gobbi M. Talking about persons, thinking about patients: an ethnographic study in critical care. Int J Nurs Stud. 2016;54(s1):122-31. https://doi.org/10.1016/j.ijnurstu.2015.02.011

18. Ford K, Tesch L, Dawborn J, Courtney-Pratt H Art, music, story: the evaluation of a person-centred arts in health programme in an acute care older persons' unit. Int J Older People N. 2018;13(2):12186-7. https://doi.org/10.1111/opn.12186

19. Cardoso OP, Campos MMMS, Oliveira MCX, Morano MTAP, Araújo MVUM, Chaves, KYS. Com palavras não sei dizer: ressignificando o cuidado através da música em pós-operatório cardiopediátrico. Rev RENE. 2017;18(5):655-62. https://doi.org/10.15253/2175-6783.2017000500013

20. Santana JCB, Dutra BS, Carlos JMM, Barros JKA. Orthothanasia in intensive care units: perception of nurses. Rev Bioét. 2017;25(1):158-67. https://doi.org/10.1590/1983-80422017251177

21. Wang L, Yang Y, Zhu J, Xie H, Jiang C, Zhang C, et al. Professional identity and mental health of rural-oriented tuition-waived medical students in Anhui Province, China. BMC Med Educ. 2019;19(1):2-10. https://doi.org/10.1186/s12909-019-1603-1 